\title{
GENOTOXICITY OF WASTEWATER SAMPLES FROM THE TEXTILE INDUSTRY DETECTED BY BROAD BEAN (VICIA $F A B A)$ MICRONUCLEUS TEST ASSAY
}

\author{
ZGÓRSKA, A. * BORGULAT, A. \\ Central Mining Institute in Katowice, Department of Water Protection \\ Plac Gwarków 1, 40-166 Katowice, Poland \\ (Zgórska, A. e-mail: azgorska@gig.eu; phone: +48-32-259-2480; fax: +48-32-259-2154) \\ (Borgulat, A.e-mail: aborgulat@gig.eu; phone: +48-32-259-2697; fax: +48-32-259-2154) \\ *Corresponding author \\ e-mail: azgorska@gig.eu; phone: +48-32-259-2480; fax: +48-32-259-2154 \\ (Received $5^{\text {th }}$ Feb 2020; accepted $22^{\text {nd }}$ May 2020)
}

\begin{abstract}
The textile wastewater induces a significant number of environmental problems, and while its toxicity has been extensively described in literature, its genotoxic and cytotoxic potential is not well known. The presence of non-biodegradable and highly toxic compounds in textile effluents make textile wastewater a possible source of ecological concern. Therefore, new data in subject matter may be very useful for their risk assessment. In the study the cytotoxicity and genotoxicity of textile wastewater derived from leather dyeing in reference to meristematic Vicia faba ( $V$. faba) root cells has been studied. The study results show that textile wastewater decreased the mitotic index (MI) as well as significantly enhanced the micronucleus frequencies (MCN) and number of chromosomal aberrations (CA) in root cells. The MCN frequencies for wastewater samples were in the range of tested concentration $6.5-43.5$ times higher than the negative control (NC). Also the correlation between the decreasing MI ratio and increasing wastewater concentration were detected. For the highest wastewater concentration the MI value was over 9 times lower than in the NC. The results indicate that textile wastewater has a genotoxic effect on plant cells and exposure to untreated wastewater can pose a potential cytotoxic and genotoxic risk.
\end{abstract}

Keywords: cytotoxicity, dye, chromosome aberrations, micronuclei, mitotic index

\section{Introduction}

Environmental impact of textile and dyeing industry is directly associated with significant amount of water consumption and significant quantities and types of chemicals used along all of the textile processing steps. Textile wastewater is a heterogeneous, poorly characterized complex mixture of several contaminants which contains a large amounts of dyes, pigments, biocides, metals, salts, surfactants, solvents, detergents and other non-biodegradable organic matters (Liang et al., 2018; Castro et al., 2019). Most of these substances poses a serious threat to exposed ecosystems. Toxicity and biodegradability of individual textile wastewater components has been the subject of many studies. Many of dyes and pigments widely used in the textile industry have been found to be toxic and genotoxic. The toxicity of dyes as individual components of textile wastewater has been widely described by authors who applies a battery of ecotoxicological tests contest organisms belonging to different trophic level and with a wide range of sensitivities (e.g. Daphnia magna, Artemia salina, Raphidoceli subcapitata, Aliivibrio fischeri, Lemna minor, Cucumis sativum, Lycopersicon esculentum, Eisenia fetida, etc.) (de Souza et al., 2007; Liang et al., 2018; Oliveira et al., 2018; Castro et al., 2019). Additionally, the publication describing the cytotoxicity, gentoxicity and mutagenicity of dyes detected using the techniques like mouse lymphoma assay, bone marrow micronucleus test and comet assay can also be found. The above-mentioned topics were the subject of work Fernandes et al. (2019) and Jha et al. (2016). 
However, in relation to textile wastewater, it should be noticed that wastewater are a complex mixture in which the dyes are only a part. Thus, the assessment of the toxicity of a single component is not sufficient to predict the interactions and joint toxicity of pollutant present in mixture even at low concentration and does not reflect the real environmental threat. While information about the potential toxicity of textile wastewater as a complex mixture can be found in trade literature (Castro et al., 2019), the knowledge about the genotoxicity and cytotoxicity of textile wastewater is still insufficient. Therefore, in order to enrich knowledge about the environmental threat posed by untreated or insufficiently treated textile wastewater the aim of the present study was to evaluate the genotoxic potential of raw textile wastewater by the use of $V$. faba micronucleus test assay. V. faba micronucleus test is a low cost, easy to handle short term assay which has been extensively used for environmental monitoring and genotoxicity assessment of various types of chemicals and wastewater (Duan et al., 1999; Iqbal, 2016). V. faba micronucleus test does not only provide information about cytotoxic and genotoxic potential of analyzed samples but also its mechanism of action on genetic material.

\section{Materials \&Methods}

\section{Wastewater sampling}

Textile wastewater samples were obtained from textile industry located in GZM Metropolis (Silesia, Poland). Within the study an average daily wastewater sample were used. The samples were collected directly from the dyeing process line in July 2019. The daily average sample was a mixture of hourly samples taken during the 24-hour production cycle. During the daily production cycle, a sample of wastewater was taken every hour and placed in a collecting vessel. Two containers of $5 \mathrm{~L}$ capacity were taken for the test. Directly after collection, a part of wastewater was sent for physicochemical analysis the rest was portioned and storage in refrigerator until use. Before each genotoxicity test the wastewater samples were thawed and filtered.

\section{Physico-chemical analysis}

Within the study an average daily wastewater sample were used. The collected textile wastewater sample was analyzed for physico-chemical parameters like: $\mathrm{pH}$, temperature, biochemical oxygen demand $\left(\mathrm{BOD}_{5}\right)$, chemical oxygen demand (COD), electrical conductivity (EC), total phosphorus (Ptot), total nitrogen (Ntot), total organic carbon (TOC) and suspended solids. Within the analyses the concentration of sulfate and chloride ions in wastewater sample was also determined. Table 1 showed some special phasico-chemical parameters of the analyzed wastewater samples.

\section{Test concentration and control}

The essence of the micronucleus test is the assessment of damage of genetic material occurring during the cell division. The genetic damages are observed in plant cells in the division phase, therefore it is importent to use the samples that do not affect the total inhibition of the mitosis process. In order to determine an appriopriate range of textile wastewater concentrations for $V$. faba micronucleus test assay an initially the root growth inhibition test for meristematic part of broad been was carried out. The root growth inhibition test was performed for 8 wastewater concentration in a range $0.78 \%$ - 
$100.00 \%$ (OECD, 1984). Based on root growth inhibition test result the $\mathrm{EC}_{50}$ value for meristematic part of $V$. faba was estimated (Table 2). According to the guidelines the target $V$. faba micronucleus test was carried out for wastewater concentrations in the range below the $\mathrm{EC}_{50}$. Therefore, the $V$. faba micronucleus test was carried out for 5 test concentrations. The highest concentration corresponded to estimated $\mathrm{EC}_{50}$ value $(15.40 \%)$ and amounted $12.50 \%$. Subsequent wastewater concentrations were prepared by the dilution method, maintaining a dilution factor of 1: 2 . Simultaneously, according to OECD (2014) recommendations in the field of genetic toxicology studies, the test was carried out using two types of test control: negative control (NC) and positive control (PC). As a NC an aerated tap water was used. The NC was used as a medium ensuring optimal culture growth conditions. A PC was used to observe damage induced by compounds with proven cancerogenic and mutagenic activity. In the micronucleus test a $1.12 \mathrm{~g} / \mathrm{L}$ solution of maleic hydrazide (Sigma Aldrich, $\mathrm{C}_{4} \mathrm{H}_{4} \mathrm{~N}_{2} \mathrm{O}_{2}$ ) was used as a PC. This compound is considered a potential carcinogen whose ability to cause micronuclei and chromosomal aberrations in plant cells has contributed to the widespread use of this compound in genotoxicity assessment (Hajjouji et al., 2007; Marcato-Romain et al., 2009; Sta et al., 2012).

Table 1. Characteristics of untreated textile wastewater

\begin{tabular}{c|c|c|c}
\hline Parameter & Unit & Value & 土SD \\
\hline $\mathrm{pH}$ & - & 6.6 & 0.2 \\
Electrical conductivity (EC) & $\mathrm{Ms} / \mathrm{cm}$ & 7500 & 380 \\
Temperature & ${ }^{\circ} \mathrm{C}$ & 14.5 & - \\
COD & $\mathrm{mg} / \mathrm{L}$ & 17500 & 2600 \\
BOD 5 & $\mathrm{mg} / \mathrm{L}$ & 2750 & \\
TOC & $\mathrm{mg} / \mathrm{L}$ & 3100 & 460 \\
$\mathrm{~N}_{\mathrm{tot}}$ & $\mathrm{mg} / \mathrm{L}$ & 380 & 57 \\
$\mathrm{P}_{\text {tot }}$ & $\mathrm{mg} / \mathrm{L}$ & 27.5 & 2.8 \\
Suspended Solid & $\mathrm{mg} / \mathrm{L}$ & 635 & 200 \\
Chloride & $\mathrm{mg} / \mathrm{L}$ & 2070 & 64 \\
Sulphates & $\mathrm{mg} / \mathrm{L}$ & 210 \\
\hline
\end{tabular}

Table 2. Impact of raw textile wastewater on growth inhibition of V.faba root

\begin{tabular}{|c|c|c|c|c|c|c|c|c|c|c|}
\hline \multirow[t]{2}{*}{ Sample } & \multicolumn{2}{|c|}{ Control } & \multicolumn{8}{|c|}{ Textile wastewater concentration [\%] } \\
\hline & NC & PC & 100 & 50 & 25 & 12.5 & 6.25 & 3.13 & 1.56 & $\mathbf{0 . 7 8}$ \\
\hline Mean root length & 4.68 & 1.10 & 0.68 & 0.91 & 1.94 & 2.37 & 2.88 & 3.54 & 4.57 & 5.38 \\
\hline$\pm \mathrm{SD}$ & \pm 1.52 & \pm 0.21 & \pm 0.37 & \pm 0.31 & \pm 0.22 & \pm 0.66 & \pm 0.88 & \pm 2.47 & \pm 2.00 & \pm 3.75 \\
\hline Growth inhibition [\%] & - & 76.5 & 85.3 & 80.5 & 58.5 & 49.3 & 38.3 & 24.3 & 2.32 & -15.1 \\
\hline $\mathrm{EC}_{50}[\%]$ & - & - & \multicolumn{8}{|c|}{15.45} \\
\hline
\end{tabular}

\section{Procedure for seeds treatment}

In the test untreated broad bean $(V . f a b a)$ seeds variety of White Windsor were used. The seeds were obtained from a local farmers' market. 72 hours before the proper micronucleus test, healthy, equal size $V$. faba seeds were pre-sterilized using a $2 \% \mathrm{H}_{2} \mathrm{O}_{2}$ solution. After sterilization the seeds were soaked in tap water for $24 \mathrm{~h}$ and placed on moist surface to germinate for $2 \div 3$ days at $20 \div 22^{\circ} \mathrm{C}$. Incubations were carried out until the roots reached the required length of $1.5-2.5 \mathrm{~cm}$. The required length should be 
understood as the length of the root obtained after seed germination, which allows to immersed the root in the tested medium without soaking the seed which protects the tested material against rotting. For each of the test concentrations and controls five seeds of $V$. faba were used. One seed means one measurement series.

\section{Micronucleus test procedure}

The $V$. faba micronucleus test was conducted based on the modified procedure described by Minissi and Lombi (1997). V. faba micronucleus test assay is a modification of the micronucleus test procedure recommended by OECD (2014) guidelines. After reaching by the $V$. faba roots a required length the seeds were peeled from the skin covering the endosperm. The seeds were handled carefully in a way that prevents damage the visible germ or seed shell. Prepared seeds were placed on styrofoam platforms covering the glass cuvette filled with adequate concentrations of textile wastewater and respectively controls solutions. The Styrofoam platform has been constructed in a way ensuring permanent contact of plant roots with the tested medium (form of hydroponic farming). After $44 \mathrm{~h}$ of incubation, $V$. faba roots were cut at 1.5-2 $\mathrm{cm}$ length and transferred to freshly prepared Carnoy solution $(99 \%$ ethanol and glacial acetic acid in a 3: 1 ratio). Prepared samples were stored in $4 \div 7^{\circ} \mathrm{C}$ in dark for $24 \mathrm{~h}$. After $24 \mathrm{~h}$, the roots were rinsed with distilled water. Within the test the possibility of indirect microscopic analysis was used. For this purpose, the roots were fixed in a $70 \%$ ethyl alcohol solution (PPH Stanlab sp. J.). Samples for analysis were stored in a refrigerator $\left(4^{\circ} \mathrm{C}\right)$. In order to prepare microscopic preparations, the roots were washed in $\mathrm{dH}_{2} \mathrm{O}$ and subjected to hydrolysis in $1 \mathrm{~N}$ hydrochloric acid solution (POCH S. A.), at a temperature of $55 \div 60^{\circ} \mathrm{C}$ for a time of $5-7$ minutes. After hydrolysis the roots were washed in $\mathrm{dH}_{2} \mathrm{O}$ and placed on microscope slides. $1.0 \div 1.5 \mathrm{~mm}$ meristem was cut, stained with a $2 \%$ orcein solution (2\% orcein in $45 \%$ glacial acetic acid) and left for $2 \div 5 \mathrm{~min}$ (dye penetration time). A cover slip was applied. Microscopic observation was carried out at $1000 \mathrm{x}$ magnification $(10 \times 100)$ using a Motic light microscope. Pictures of the cells were taken with the MOTICam 100 camera and developed in the Motic Images program. For each of the test concentrations and controls, the test was performed in 5 replicates. In each replication, microscopic observations were made for 1000 cells $(1$ series $=5000$ cells analyzed / concentration). Based on the results of microscopic analysis, the following parameters were assessed: the value of the mitotic index (IM), the frequency of chromosome aberrations in cells during mitotic division (CA), as well as the incidence of micronucleus aberrations in the observed cells (MCN).

\section{Scoring the mitotic indexd (MI)}

Five slides for each wastewater concentration and control were prepared. Nearly 5000 cells ( 1000 cells per slide) were subjected to microscopic analysis to determine the mitotic index (MI). The MI value was calculated as the quotient of a total number of dividing cells to total number of cells examined.

\section{Scoring the micronucleus (MCN) and chromosomal aberrations (CA) frequency}

About 1000 meristematic cells were scored for each slide. The MCN frequency was calculated from the number of cells with scored MCN aberrations divided by the total cells scored for slide and expressed in terms of MCN/1000 cells. Adequately, the CA 
were analyzed by microscope observing about 400 cells at the stage of mitosis per slide. During the analyses a different types of the aberration cells were observed and recorded.

\section{Statistical analysis}

Statistical analysis was performed using MS EXcel software. The obtained results are expressed as an average value and standard errors.

\section{Results \& Discussion}

MI is considered as an indicator that allows to estimate the frequency of cellular division. The results of the analysis (Table 3) show that textile wastewater induced mitotic delay and decrease MI frequency in meristematic root cell of $V$. faba. The MI index was significantly different for all analyzed samples, however in all test series a reliable and reproducible results were obtained. Compared to NC, MI frequencies decreased with increasing wastewater concentration. Textile wastewater affected the inhibition of the cell division from $13.67 \%$ to $54.85 \%$. The $54.85 \%$ reduction of MI versus $\mathrm{NC}$ were detected in the $V$. faba root tips after treatment with the highest wastewater concentration (12.50\%). Similar results were obtained by Giorgetti, which evaluates the geneotoxicity of raw effluents from textile industry. Estimated MI value was heavily reduced from $19.58 \%$ in the $\mathrm{NC}$ to $3.82 \%$ for raw effluent. For undiluted textile wastewater the mitosis activity inhibition was $80.49 \%$ (Giorgetti et al., 2011).

Table 3. Value of mitotic index (MI) in root tip cells of V. faba treated with textile wastewater in various concentrations

\begin{tabular}{c|c|c|c|c|c|c|c}
\hline $\begin{array}{c}\text { Wastewater } \\
\text { concentration }\end{array}$ & \multicolumn{7}{|c}{ Mitotix index per 1000 Vicia faba cells in 5 root tips [\%] } \\
\hline Series & 1 & 2 & 3 & 4 & 5 & Mean & \pm SE \\
\hline $12.5 \%$ & 2.13 & 1.45 & 0.74 & 2.56 & 2.09 & 1.79 & \pm 0.71 \\
$6.25 \%$ & 7.05 & 8.14 & 8.62 & 6.99 & 6.2 & 7.40 & \pm 0.97 \\
$3.125 \%$ & 8.3 & 7.12 & 8.34 & 9.76 & 8.98 & 8.45 & \pm 0.99 \\
$1.56 \%$ & 10.15 & 10.78 & 11.14 & 15.12 & 11.23 & 11.68 & \pm 1.97 \\
$0.78 \%$ & 13.56 & 15.24 & 14.98 & 10.77 & 16.2 & 14.15 & \pm 2.11 \\
NC & 14.23 & 16.53 & 18.34 & 15.23 & 17.65 & 16.39 & \pm 1.69 \\
PC & 1.89 & 1.76 & 0.96 & 1.45 & 1.15 & 1.44 & \pm 0.39 \\
\hline
\end{tabular}

The determined values of MI confirms the results obtained in growth inhibition test. Root growth reflects the toxicity in the elongation plant zone, as root growth inhibition is caused by the occurrence of chromosol aberration and a reduction in the root length of $V$. faba exposed to textile wastewater (Bhat et al., 2017). Both test results (growth inhibition, micronucleus test) confirm that textile wastewater in concentration above $12.50 \%$ are highly toxic and affect significant growth inhibition, which exceeds the $80 \%$ for wastewater concentration above $50 \%$. Maximum inhibition of cell division noted in the micronucleus test directly coincides to a $\mathrm{EC}_{50}(15.45 \%)$ estimated in growth inhibition test for meristematic part of $V$. faba (Table 2). A comparable impact level of textile wastewater on plant cells has been shown by Samuel (2010). Estimated $\mathrm{EC}_{50}$ value of textile industry effluent for rhizosphere part of Allim cepa amounted $16 \%$ after $96 \mathrm{~h}$ of exposition. 
The genotoxic effects expressed as the number of micronuclei (MCN) induced in $V$. faba root cells are given in Table 4. The reference point in the text is the PC that induced a significantly high number of micronuclei in root tips of $V$. faba (24.42\%o). The number of micronuclei inducted by textile wastewater was lower according to PC (twice lower) and simultaneously much higher in reference to NC (43 times higher). Conducted studies proves that textile wastewater, even at low concentrations, causes damage to the genetic material of tested plants. The number of micronuclei identified in root cells exposed to wastewater sample at the lowest concentration reach 1.58\% (wastewater concentration $0.78 \%$ ) and increased with increasing wastewater concentration up to value 10.44\% (wastewater concentration 12.50\%). Examples of micronucleus aberrations observed in $V$. faba meristematic cells are presented in Figure 1.

Table 4. MCN frequencies in root tip cells of $V$. faba treated with textile wastewater in individual concentrations

\begin{tabular}{c|c|c|c|c|c|c|c}
\hline $\begin{array}{c}\text { Wastewater } \\
\text { concentration }\end{array}$ & \multicolumn{5}{|c|}{ MCN per 1000 Vicia faba cells in 5 root tips [\%o] } & Mean & \\
\hline Series & 1 & 2 & 3 & 4 & 5 & Mean & \pm SE \\
\hline $12.5 \%$ & 11.89 & 10.98 & 9.77 & 11.02 & 8.56 & 10.44 & \pm 1.29 \\
$6.25 \%$ & 6.54 & 9.28 & 7.13 & 7.25 & 6.14 & 7.27 & \pm 1.21 \\
$3.125 \%$ & 4.56 & 10.56 & 5.12 & 4.16 & 6.55 & 6.19 & \pm 2.61 \\
$1.56 \%$ & 2.94 & 3.15 & 3.89 & 2.06 & 3.85 & 3.18 & \pm 0.75 \\
$0.78 \%$ & 1.03 & 0.99 & 1.45 & 2.43 & 2.01 & 1.58 & \pm 0.63 \\
NC & 0.78 & 0.00 & 0.00 & 0.12 & 0.32 & 0.24 & \pm 0.33 \\
PC & 24.32 & 21.34 & 19.87 & 26.75 & 29.84 & 24.42 & \pm 4.03 \\
\hline
\end{tabular}

The study result shows a clastogenic effect, evidenced by the induction of CA at used concentration. During the micronucleus test the major CA were noted as fragments, laggards, vagrants and chromosomal bridges (Figure 2). The lowest CA frequency was observed to be $0.39 \%$ in control sample (NC). In turn the highest frequency of CA (18.78\%) was found to be in $12.50 \%$ concentration of textile wastewater. A PC, whose genotoxicity has been confirmed, induced chromosomal aberrations at the level $3.52 \%$. An increasing with wastewater concentration percentage of CA showed positive correlation with sample concentration (Table 5).

Additionally, the studies proved the usefulness of $V$. faba micronucleus test for assessing the genotoxic potential of such complex mixtures as textile wastewater. Similar conclusions based on research were formulated by Bhat (2017). Author indicate in his work that the $V$. faba (broad bean) bioassay is used extensively to evaluate toxic substances in the environment and is an excellent bioassay for toxicological observations. As an advantage of the method author indicates the high sensitivity and economic profitability of the test. Moreover, author marks the that broad bean cells are quite large which makes the chromosomes more visible and finally makes the chromosomal-aberration evaluation easier (Bhat et al., 2017). The study result confirm that plant test model based on the analysis of induced changes in meristematic cells of $V$. faba is effective and appropriate assay for detection of genotoxicity and cytotoxicity of environmental samples. 

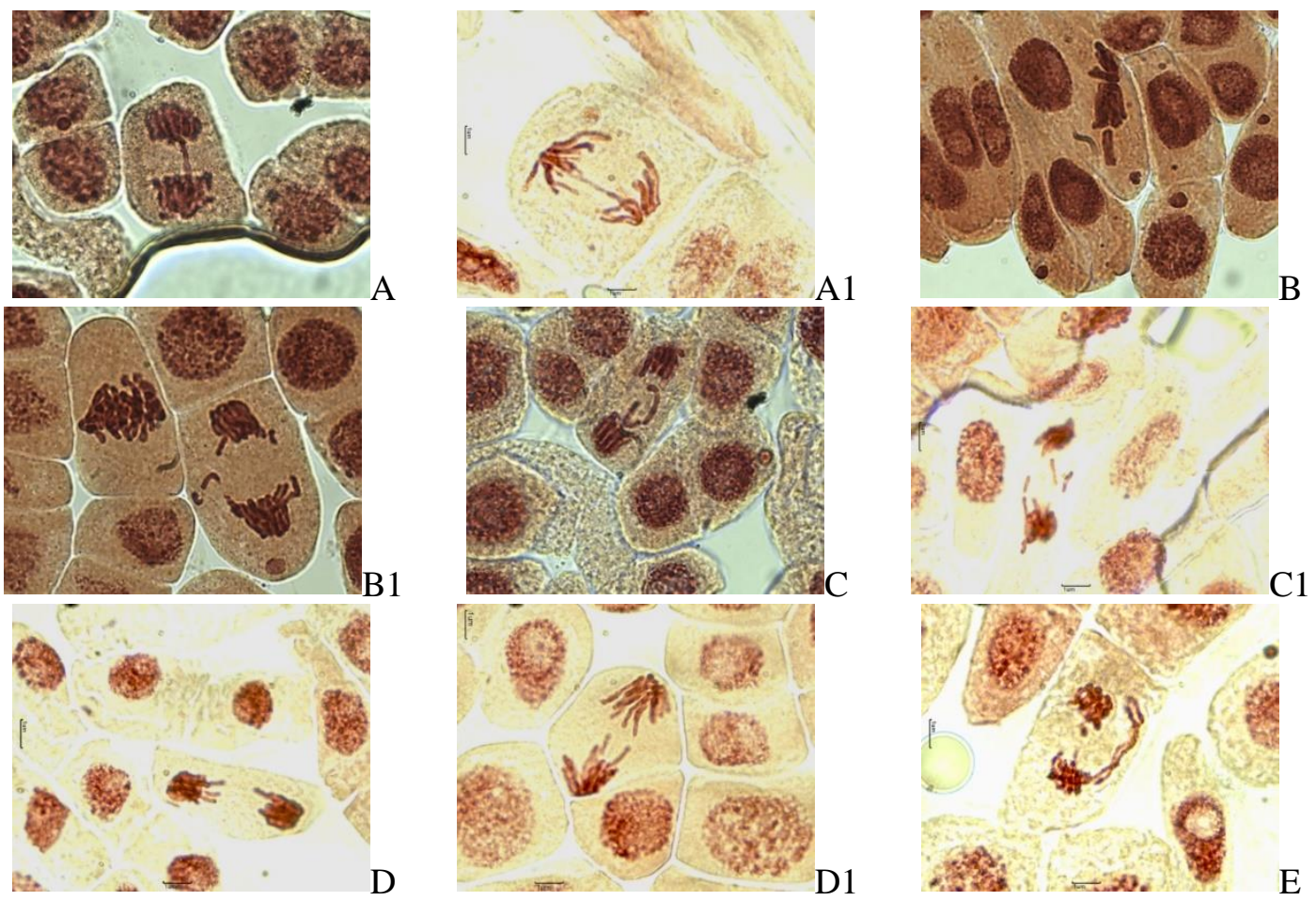

Figure 1. Examples of micronucleus and chromosomal aberrations observed in Vicia faba root cells after exposure to textile wastewater: ${ }^{A, A l}$ chromosome bridge ${ }^{B, B l}$ fragments of chromosome; ${ }^{C, C l}$ lagger chromosome; ${ }^{D, D l}$ vagrant chromosome; ${ }^{E}$ multi aberration
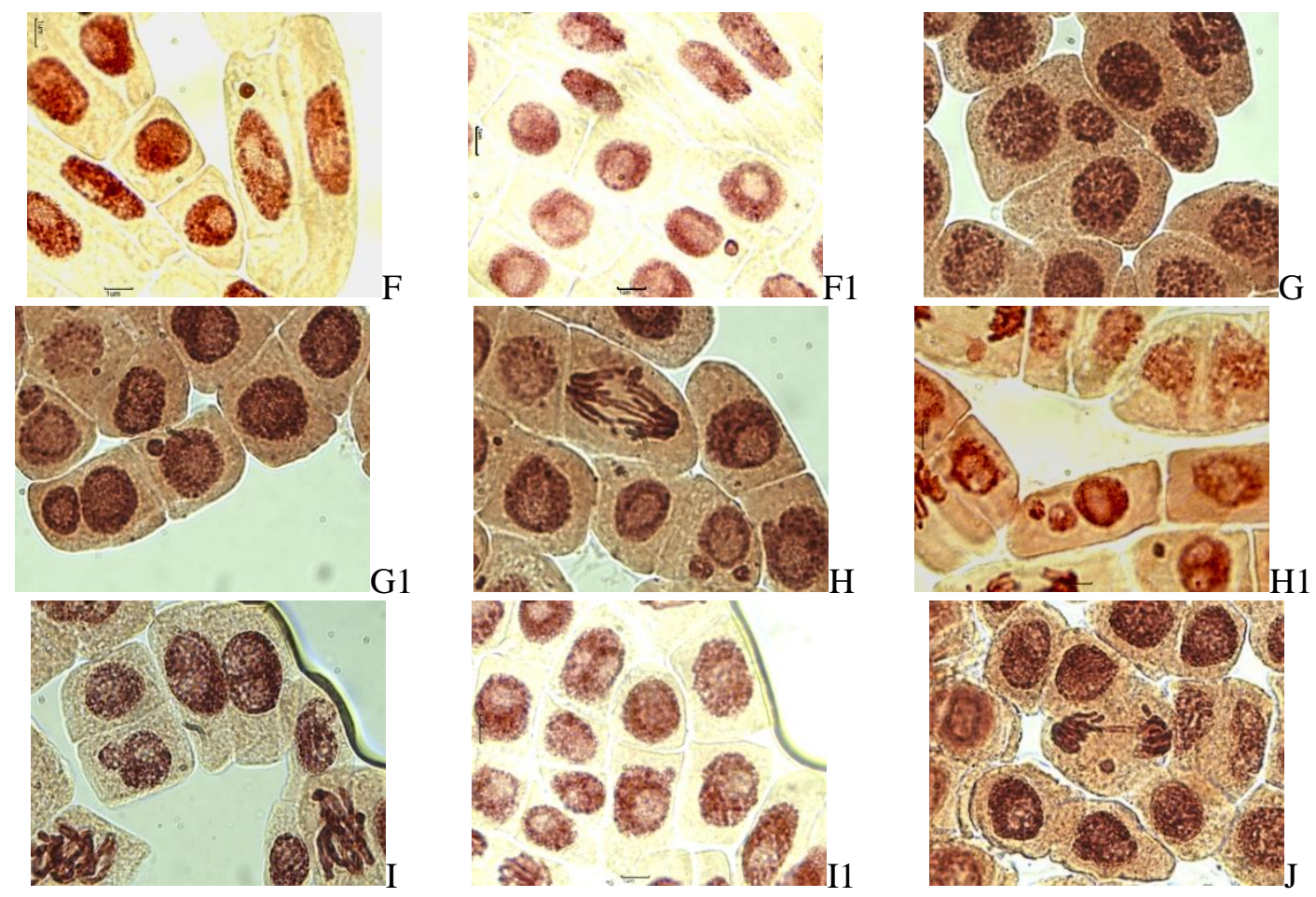

Figure 2. Examples of micronucleus aberration observed in V.faba root cells after exposure to textile wastewater: ${ }^{F, F I}$ micronuclei; ${ }^{G, G l}$ meganuclei ${ }^{H, H I}$ multinuclei; ${ }^{I, I I}$ bud chromosome; ${ }^{J}$ micronuclei in anaphase 
Table 5. CA frequencies in root tip cells of $V$. faba treated with textile wastewater in individual concentrations

\begin{tabular}{c|c|c|c|c|c|c|c}
\hline $\begin{array}{c}\text { Wastewater } \\
\text { concentration }\end{array}$ & \multicolumn{7}{c}{ CA per 400 Vicia faba cells in 5 root tips [\%] } \\
\hline Series & 1 & 2 & 3 & 4 & 5 & Mean & \pm SE \\
\hline $12.5 \%$ & 18.67 & 17.34 & 21.14 & 18.32 & 18.45 & 18.78 & \pm 1.41 \\
$6.25 \%$ & 11.23 & 10.98 & 9.87 & 11.34 & 12.14 & 11.11 & 0.82 \\
$3.125 \%$ & 7.85 & 7.64 & 8.14 & 6.14 & 7.33 & 7.42 & \pm 0.76 \\
$1.56 \%$ & 3.87 & 4.1 & 2.88 & 3.95 & 4.13 & 3.79 & \pm 0.52 \\
$0.78 \%$ & 2.65 & 1.89 & 2.54 & 2.32 & 1.99 & 2.28 & \pm 0.33 \\
NC & 0.65 & 0.45 & 0.00 & 0.87 & 0.00 & 0.39 & \pm 0.39 \\
PC & 3.45 & 4.21 & 2.98 & 3.21 & 3.75 & 3.52 & \pm 0.48 \\
\hline
\end{tabular}

\section{Conclusion}

The results of the study showed toxic effect posed by untreated textile wastewater on the meristematic cell of $V$. faba. The test results demonstrated a positive correlation between the wastewater concentration and toxic effect expressed in the indicators form as MI, MCN frequencies and CA. Conducted research proves that textile wastewater have a genotoxic potential. The results imply that the wastewater could result in environmental contamination even at low concentration and exposure to wastewater might posed potential risk conducted cytogenetic damages induced in exposed organisms cells. Additionally, the study results imply that $V$. faba micronucleus assay as a sensitive and repeatable method can successfully use for testing cytotoxic and genotoxic risk for both, individual (chemical) substances, which have been already proved, as well as complex mixtures, such as textile wastewater which often forming a difficult to identify. Moreover, described method is cheaper than other techniques that may be used in genotoxicological studies (e.g. FISG, GISH or RT-PCR) and, what is particularly important, does not require sterile working conditions.

Acknowledgements. The work was carried out in Central Mining Institute as a part of the statutory work №11158019 co-funded by the Polish Ministry of Science and Higher Education.

\section{REFERENCES}

[1] Bhat, S. A., Singh, J., Singh, K., Vig, A. P. (2017): Genotoxicity Monitoring of Industrial Wastes Using Plant Bioassays and Management through Vermitechnology: A Review. Agriculture and Natural Resources 51(5): 325-37.

[2] Castro, A. M. , Nogueira, V., Lopez, I., Rocha-Santos, T. (2019): Evaluation of the Potential Toxicity of E Ffl Uents from the Textile Industry before and after Treatment. Applied Sciences 9: 3804. doi:10.3390/app9183804.

[3] De Souza, U., Guelli, S. M. A., Forgiarini, E., Augusto, A. (2007): Toxicity of Textile Dyes and Their Degradation by the Enzyme Horseradish Peroxidase (HRP). - Journal of Hazardous Materials 147(3): 1073-78.

[4] Duan, C. Q., Hu, B., Jiang, X. H., Wen, C. H., Wang, Z., Wang, Y. X. (1999): Genotoxicity of Water Samples from Dianchi Lake Detected by the Vicia Faba Micronucleus Test. - Mutation Research - Fundamental and Molecular Mechanisms of Mutagenesis 426(2): 121-25. 
[5] Fernandes, F. H., de Aragão Umbuzeiro, G., Fávero-Salvadori, D. M. (2019): Genotoxicity of Textile Dye C.I. Disperse Blue 291 in Mouse Bone Marrow. - Mutation Research - Genetic Toxicology and Environmental Mutagenesis 837: 48-51.

[6] Giorgetti, L., Talouizte, H., Merzouki, M., Caltavuturo, L., Geri, C., Frassinetti, S. (2011): Genotoxicity evaluation of effluents from textile industries of the region FezBoulmane, Morocco: A case study. - Ecotoxicology and Environmental Safety 74(8): 2275-2283.

[7] Hajjouji, H. El., Pinelli, E., Guiresse, M., Merlina, G., Revel, J. C., Hafidi, M. (2007): Assessment of the Genotoxicity of Olive Mill Waste Water (OMWW) with the Vicia Faba Micronucleus Test. - Mutation Research - Genetic Toxicology and Environmental Mutagenesis 634(1-2): 25-31.

[8] Iqbal, M. (2016): Vicia Faba Bioassay for Environmental Toxicity Monitoring: A Review. - Chemosphere 144: 785-802.

[9] Jha, P., Jobby, R., Desai, N. S. (2016): Remediation of Textile Azo Dye Acid Red 114 by Hairy Roots of Ipomoea Carnea Jacq. and Assessment of Degraded Dye Toxicity with Human Keratinocyte Cell Line. - Journal of Hazardous Materials 311: 158-67.

[10] Liang, J., Ning, X., Kong, M., Liu, D., Wang, G., Cai, H., Sun, J., Zhang, Y., Lu, X., Yuan, Y. (2017): Elimination and Ecotoxicity Evaluation of Phthalic Acid Esters from Textile-Dyeing Wastewater. - Environmental Pollution 231: 115-22.

[11] Liang, J., Ning, X., Sun, J., Song, J., Lu, J., Cai, H., Hong, Y. (2018): Toxicity Evaluation of Textile Dyeing Effluent and Its Possible Relationship with Chemical Oxygen Demand. - Ecotoxicology and Environmental Safety 166: 56-62.

[12] Marcato-Romain, C. E., Pinelli, E., Pourrut, B., Silvestre, J., Guiresse, M. (2009): Assessment of the Genotoxicity of $\mathrm{Cu}$ and $\mathrm{Zn}$ in Raw and Anaerobically Digested Slurry with the Vicia Faba Micronucleus Test. - Mutation Research - Genetic Toxicology and Environmental Mutagenesis 672(2): 113-18.

[13] Minissi, S., Lombi, E. (1997): Heavy Metal Content and Mutagenic Activity, Evaluated by Vicia Faba Micronucleus Test, of Tiber River Sediments. - Mutation Research 393: 17-21.

[14] Oliveira, G. A. R., Leme, D. M., de Lapuente, J., Brito, L. B., Porredón, C., de Brito Rodrigues, L., Brull, N. (2018): A Test Battery for Assessing the Ecotoxic Effects of Textile Dyes. - Chemico-Biological Interactions 291: 171-79.

[15] Organization for Economic Cooperation and Development (1984): Terrestrial Plants, Growth Test. - Test No. 208.

[16] Organization for Economic Cooperation and Development (2014): In vitro Mammalian Cell Micronucleus Test. - Test No. 487.

[17] Samuel, O. B., Osuala, F. I., Odeigah, P. G. C. (2010): Cytogenotoxicity Evaluation of Two Industrial Effluents Using Allium Cepa Assay. - African Journal of Environmental Science and Technology 4(1): 21-27.

[18] Sta, C., Ledoigt, G., Ferjani, E., Goupil, P. (2012): Exposure of Vicia Faba to Sulcotrione Pesticide Induced Genotoxicity. - Pesticide Biochemistry and Physiology 103(1): 9-14. 